\title{
Effects of crop viruses on wild plants
}

$8{ }^{1}$ Department of Plant Biology and ${ }^{2}$ Program in Ecology, Evolution, and Behavioral Biology,

9 Michigan State University, East Lansing, MI 48824 USA

$10{ }^{3}$ Department of Ecology and Evolutionary Biology, University of Kansas, Lawrence, KS 66045

11 USA

\section{*Correspondence author:}

carolynm@msu.edu; telephone: +1-517-355-4690; fax: +1-517 353-2369

17

18

19 


\section{Abstract}

23 Global land conversion and intensification of agriculture mean that remnant native plant

24 populations are increasingly exposed to crop viruses. What are the consequences for wild plants?

25 In natural unmanaged systems, the key consideration is how crop virus infection influences plant

26 fitness. Field studies of virus effects on wild plant fitness are scant. Approaches include (i)

27 observational studies, (ii) studies of experimental plants with natural infection, and (iii) studies

28 of experimental plants with experimental infection, withmost studies focused on viruses in

29 theLuteoviridae and Potyviridae families. Fitness effects documented are largely neutral to

30 negative. Crop virus influence on wild plants merits attention in ecological conservation and 31 restoration. 


\section{Introduction}

34 Humanity's appetitefor food, fuel, and fiber is growing. To feed it, approximately one-half of the

35 Earth’s terrestrial surface has been converted to agricultural crops and rangeland [1], and this

36 fraction will likely increase. When agriculture first developed some 10,000 years ago, cultivated

37 fields were a small fraction of the landscape, with crops surrounded by a matrix of wild

38 vegetation. Farmers, and later plant pathologists, worked hard to defend crops from what must

39 have seemed to be an overwhelmingly large natural reservoir of viruses and other pests. Now in

40 many regions the landscape balance has been reversed, with natural vegetation present in ever-

41 shrinkingremnants within an expansive sea of crops and managed fields. Wildlands are regularly

42 exposed toviruliferous vectors effluxing from agroecosystems, and there is increasingevidence

43 about the potential for deleterious effects[2,3*].Thus, a new question must be asked: What

44 influence(s) are domesticated landscapes having on plant virus ecology and evolution?

45 Specifically, what effects do crop viruses have on the fitness of wild plants? This is an urgent

46 question whose timeliness is compounded by the need to protect wild plant populations from the

47 rising threats of climate change. Unfortunately, due to a number of constraints including

48 disciplinary history[4] and biosafety logistics [3*], there is a surprising lack of empirical data.We

49 thus explorerelevant published studies from the beginning of modern plant virology (1960s) to

50 the present and call for a new era of investigation.

51 Are crop viruses pathogenic in wild plants?

52 
53 Most of the viruses that are central to our knowledge of plant virology are crop-associated, and

54 were first recognized because of their presence in, and often damage to, agricultural plants[5].

55 We thus define "crop viruses" as those known to cause notable yield or economic loss in crops,

56 including forage, in contrast to "wild” viruses that are associated primarily with non-crop

57 vegetation. Many crop viruses are generalists that also caninfect "wild" or unmanaged plant

58 populations, which we define as non-cultivated plant populations in which changes in population

59 size or genetic composition are not under direct human control [6*].It is clear from retrospective

60 analyses that agricultural expansion and intensification have capacity to drive changes in viral

61 taxa, such as the proliferation of potyviruses that occurred in parallel with the first development

62 of cropping systems [7]. Does association with crops make plant viruses more or less

63 pathogenic? The classical hypothesis has been that agricultural association would tend to favor

64 pathogenicity [8]. Given that crop plants represent a subset of plant life styles (mostly annual,

65 fast growing) and environments (highly managed in modern agriculture), selective pressures

66 might favor viruses that could propagate quickly and be readily transmitted to new hosts,

67 characteristics associated with pathogenicity (in fact, the situation is likely more complex [8]).

68 Our focus here is on whether pathogenic crop viruses have consequences for wild plants.

69 One expectation is that effects will be negative - i.e., viruses pathogenic on crops will also be

70 pathogenic on wild plants. However, plant breeding has sometimes increased crop growth rates

71 at the expense of crop resistance[9,10], so it is possible that viruses operating in such hosts might

72 maintain fewer defenses (e.g., silencing suppressors) themselves. Thus, crop viruses might be

73 pathogenic in crops, but have little effects on better defended wild hosts.Finally, it has also been

74 suggested that crop viruses may provide some benefitsto plants, such as tolerance to

75 dessication[11,12] or drought[13](but see[14]). 


\section{Quantifying virus influence on plant fitness in the field}

77 There is much less empirical data about the effects of crop viruses on wild plants than on crop

78 and model species. Nonetheless, there are interesting indications that virus infection in wild

79 plants, as in crop plants, can modulate plant physiology and response to environmental resources

80 and stresses. For example, infection increases the response of native grasses to resource release

81 with simulated grazing [15]. Evaluation of the molecular and physiology mechanisms of wild

82 plant - crop virus interactions is thus valuable. Here we wish to highlight the critical need for

83 investigation of virus effects at the whole plant level, namely effects on wild plant fitness in the

84 field. "Fitness” is an evolutionary biology term that describes how successfully an individual

85 propagates its genes [16]. We thus use the term "fitness" to mean the contribution of an

86 individual, in terms of offspring, to the next generation [17]. Fitness is a cumulative term that

87 integrates plant survival and reproduction at different life stages (Fig. 1A). It is distinct from

88 “yield," which quantifies commodity production by a population of plants in a given area (e.g.,

89 bushels of maize harvested per acre). Fitness is of central importance in plant ecology because it

90 is a key determinant of plant population and community dynamics, as well as plant evolution

91 (Fig. 1B).

92 To evaluate virus effects, attention is often paid to symptoms[8], such as distinctive

93 discoloration or abnormal morphology, and to growth measurements, such as plant height or

94 biomass production. All of these metrics have value. To quantify virus effects on fitness,

95 however, what is most needed are measures of individual fitness components across the plant life

96 cycle including survivorship to specific life stages, and metrics of reproduction such as

97 probability of flowering and quantity of seed produced (Fig 1A).These metrics are useful on their

98 own and gain even more power when integrated by models to estimate overall fitness effects, 
99 using approaches such as matrix modelling [18*,19*] and aster models [17]. For wild plants,

100 measures of fitness components are best obtained in outdoor field settings where individuals

101 experience fluctuations in weather and resource availability, natural disturbances, and true

102 biologically active soils with sufficient rooting depth. In plant science, it is increasingly

103 recognized that pots can cause growth artefacts [20] and that plants grown in static, controlled

104 situations may not manifest the full range of phenotypes evident in dynamic

105 environments[21]typical of natural settings. Thus, the most convincing documentation of crop

106 virus effects on wild plants is likely to come from studies of fitness effects in the field. Such

107 studies typically employ one of three different approaches and require consideration of multiple

108 issues, including biosafety requirements and interpretation of causality (Box 1 and graphical

109 abstract).

110 Crop virus influence on wild plant fitness components is largely negative to neutral

111 To summarize current understanding, we surveyed the ecological and virological

112 literature. Because field studies of virus effects on wild plant fitness are scant, we

113 includednaturalized pasture species in our definition of “wild” plants and searched as far back as

114 the 1960's when plant virus detection methods first began to modernize. In17publications, we

115 found reports of 20 studies that examined the effect of crop viruses of any type on fitness or

116 fitness components of wild plants in the field. Some individual publications described several

117 studies each $\left[18,22,23^{*}\right]$; in another case, we counted two separate publications as different time

118 points of a single longer-term study[24,25]. Most of the studies examinedeither Barley and

119 Cereal yellow dwarf viruses (generaLuteovirusand Polerovirus, family Luteoviridae: B/CYDVs)

120 in grasses, which have become a model system in plant virus ecology, or potyviruses(family 
121 Potyviridae); a few crop viruses in theBromoviridae,Geminiviridae, Secoviridae, and

122 Tymoviridaefamilies were also considered(Table 1).

123 The field studies were conducted in temperate or Mediterranean climate systems in

124 Australia, Japan, the UK, and the USA (Table 1). Most studies were just 1-2 yrs in length with 125 two longer studies [23-25].Each study quantified at least one fitness component, sometimes

126 several, and two presented integrated measures of fitness $[18,19]$. Many studies also quantified 127 growth metrics. About $1 / 3$ of the studies examined annual plants, the rest perennials (including 128 biennials). Even among this set of “wild” plants, however, all of the subjects were herbaceous 129 species from families well-represented in agriculture, and $40 \%$ of the subject groups represented 130 species exotic to the study region.

131 Across all study types, the documented effects of crop viruses on fitness components of 132 wild plants were largely negative to neutral (Fig. 2). There was no qualitative difference in this 133 tendency across the six crop virus families represented. About one-half of the studies (9/20)

134 measured crop virus effects on host survivorship with 89\% (8/9) reporting negative effects on

135 some or all host genotypes. Of the 19studies that reported measures of reproductive success, 84\% $136(16 / 19)$ observed only negative to neutral effects, with nearly one-half (9/19) reporting solely 137 negative effects. Negative reproductive effects associated with infection included reduction in 138 probability of flowering [22], inflorescence number [23*,26,27], reproductive biomass [28*], 139 numbers of fruits andof male flowers [29], and overall seed production or

140 fecundity[15,19*,22,23*,25]. Growth metrics, while not direct measures of fitness, also were 141 negatively associated with infection in $88 \%(13 / 15)$ of the studies reporting them. Negative 142 growth effects included reductions in leaf number [22,30]; height [15,22,31-33*]; tiller number 143 [15,27], and growth rate, vigor, or overall biomass production [15,19*,23*,25,28*,33*-35]. 
145 the field. Prendeville et al. [18*]reported that in fitness models inoculation with Zucchini yellow

146 mosaic virus(genus Potyvirus, family Potyviridae) increased population growth rate in one of

147 three populations of an annual gourd, although significant differences were not evident in

148 individual fitness components. In other cases, infection had positive effects on plant

149 reproductionor phenologybut not survivorship. In a survey of annual weedy grasses (Method 1),

150 for example, the panicle length of Setariapumilla ssp. pumilla was positively associated with

151 luteovirus infection in one of two years [33*]. In our review, observational studies (Method 1,

152 Box 1) had a somewhat greater proportion of neutral to positive results, perhaps because of non-

153 random processes in infection acquisition, or because the logistics of more controlled

154 experiments (Method 3) favor inoculation of young plants that in turn may show greater

155 responses to inoculation than mature individuals. In three other studies, virus infection altered

156 plants traits in ways that might increase fitness. However, given the overall results of each

157 study, evidence of increased fitness was not readily apparent. In the first example, Turnip mosaic

158 virus (genus Potyvirus, family Potyviridae) infection reducedfleabeetle damage in wild Brassica

159 oleracea [27], but fungal damage rose, and seed production and survivorship were reduced. In

160 the second example, Catherall [20] found that Barley yellow dwarf virusinfection stimulated

161 early growth, tillering, and spring biomass production in mowed Loliumperenne. However, this

162 virus-induced shift in phenologylikely did not increase host fitness because infected plants

163 produced less total herbage and the ratio of fertile tovegetative tillers was reduced. Moreover, in

164 communities with clover, virus infection in Lolium favored clover production.In the third

165 example, Mackenzie reported that infected Primula tended to bloom earlier[30]; we counted this

166 as a positive fitness effect, but it might not be if, for example, this timing is not optimal for 
167 pollinators.Our findings of limited positive effects of crop virus infection contrast with notable

168 positive effects on host survivorship under herbivory in a rare study of wild plants with wild

169 virus infection[36]. Overall, our summary supports concerns raised by recent greenhouse

170 inoculation trials that crop viruses have substantial potential to harm natural plant populations $171\left[3^{*}\right]$.

\section{Conclusions}

173 Increased understanding of the effects of crop viruses on wild vegetation is important for two

174 reasons. First, wild plants are tremendously diverse in terms of morphology, physiology, and life

175 cycle. By understanding how viruses interact with these species, we will gain a broader

176 understanding of plant-virus interactions in general. Second, wild plants are increasingly limited

177 to habitat patches that are surrounded by an agricultural matrix, and thus have increased

178 exposure to crop viruses. Such viruses thus deserve attention from a conservation perspective.

Our focus was to explore the effects of crop viruses on plant fitness, given that fitness

180 measurements are central for ecological and evolutionary investigations. We found that most

181 reported effects of crop viruses on wild plants are neutral or negative. The number of available

182 studies is, however, limited. To overcome past biases, new studies need to be done with (1) a

183 wide diversity of types of viruses, (2) a wide diversity of types of plants, and (3) in the context of

184 diverse environments. The latter is particularly important since there is clearly not a single effect

185 of viruses on plant fitness, but likely a range of effects depending on environmental context.

We thus advocate for a new generation of field studies of virus effects on plant fitness.

187 For those viruses for which field experiments are feasible, we suggest field factorial experiments

188 where virus-inoculated and mock-inoculated plants are grown, for example, with reduced vs. 
enhanced water treatments or with exposure to herbivores vs. protection from herbivores (e.g.,

190 via cages, insecticides). Such environmental manipulations are commonly done by plant

191 ecologists. It is now time to integrate such ecological approaches with questions in virology.

\section{Acknowledgements}

193 We thank Janis Antonovics, Kristin Mercer, Ruth Shaw,and Plant Virus Ecology Network

194 colleagues for helpful discussion and feedback, and Pauline Bernardo and Kasey Nicholoff for 195 assistance with figures. This work was supported by a University of Kansas General Research 196 Fund 2301545 (HMA), and by US National Science Foundation grant no. IOS-0639139, DOE 197 Office of Science BER DE-FC02-07ER64494, USDA NIFA Sustainable BiofuelsProgram 198 Award 2011-67009-30137, and MSU AgBioResearch (CMM).

\section{References}

1. Millennium Ecosystem Assessment: Ecosystems and Human Well-Being: Current State and Trends Washington, DC: Island Press; 2005.

2. Jones RAC, Coutts BA: Spread of introduced viruses to new plants in natural ecosystems and the threat this poses to plant biodiversity. Molecular Plant Pathology 2015, 16:541-545.

*3. Vincent SJ, Coutts BA, Jones RAC: Effects of introduced and indigenous viruses on native plants: Exploring their disease causing potential at the agro-ecological interface. PLOS ONE 2014, 9:e91224. 
*A greenhouse study that is unique in its examination of many viruses (both introduced and indigenous viruses) and many native Australian plant species. The research focuses on the ability of viruses to infect, cause symptoms, and alter plant growth.

212 4. Malmstrom CM, Melcher U, Bosque-Perez NA: The expanding field of plant virus ecology:

213 historical foundations, knowledge gaps, and research directions. Virus Res 2011, $214 \quad$ 159:84-94.

215 5. Wren JD, Roossinck MJ, Nelson RS, Scheets K, Palmer MW, Melcher U: Plant virus 216 biodiversity and ecology. PLoS Biology 2006, 4:314-315.

217 *6. Alexander HM, Mauck KE, Whitfield AE, Garrett KA, Malmstrom CM: Plant-virus interactions and the agro-ecological interface. European Journal of Plant Pathology

7. Gibbs AJ, Ohshima K, Phillips MJ, Gibbs MJ: The prehistory of potyviruses: their initial radiation was during the dawn of agriculture. PLoS One 2008, 3:e2523.

8. Fraile A, García-Arenal F: Environment and evolution modulate plant virus pathogenesis.

9. Schrotenboer AC, Allen MS, Malmstrom CM: Modification of native grasses for biofuel production may increase virus susceptibility. Global Change Biology Bioenergy 2011,

10. Larson G, Piperno DR, Allaby RG, Purugganan MD, Andersson L, Arroyo-Kalin M, Barton L, Climer Vigueira C, Denham T, Dobney K, et al.: Current perspectives and the 
future of domestication studies. Proceedings of the National Academy of Sciences 2014, 111:6139-6146.

234 11. Xu P, Chen F, Mannas JP, Feldman T, Sumner LW, Roossinck MJ: Virus infection

235 improves drought tolerance. New Phytologist 2008, 180:911-921.

236 12. Westwood JH, McCann L, Naish M, Dixon H, Murphy AM, Stancombe MA, Bennett MH,

237 Powell G, Webb AAR, Carr JP: A viral RNA silencing suppressor interferes with

14. Prasch CM, Sonnewald U: Simultaneous application of heat, drought, and virus to

13. Davis TS, Bosque-Pérez NA, Foote NE, Magney T, Eigenbrode SD: Environmentally dependent host-pathogen and vector-pathogen interactions in the Barley yellow dwarf virus pathosystem. Journal of Applied Ecology 2015:n/a-n/a. abscisic acid-mediated signalling and induces drought tolerance in Arabidopsis thaliana. Molecular Plant Pathology 2013, 14:158-170.

Arabidopsis plants reveals significant shifts in signaling networks. Plant Physiol 2013, 162:1849-1866.

15. Malmstrom CM, Stoner CJ, Brandenburg S, Newton LA: Virus infection and grazing exert counteracting influences on survivorship of native bunchgrass seedlings competing with invasive exotics. Journal of Ecology 2006, 94:264-275.

16. Antonovics J, Alexander HM: The concept of fitness in plant-fungal pathogen systems. In Plant Disease Epidemiology. Genetics, Resistance, and Management. Edited by Leonard KJ, Fry WE: McGraw-Hill; 1989:185-214. vol 2.]

17. Shaw RG, Geyer CJ, Wagenius S, Hangelbroek HH, Etterson JR: Unifying life-history analyses for inference of fitness and population growth. American Naturalist 2008, 172:E35-E47. 
255 *18. Prendeville HR, Tenhumberg B, Pilson D: Effects of virus on plant fecundity and

256 population dynamics. New Phytol 2014, 202:1346-1356.

257 *A study that examines virus effects on annual plant fitness. This is one of only two

258 publications that uses matrix-based demographic models as a way to integrate

259 information on virus effects across the entire life cycle.

260 *19. Godfree RC, Woods MJ, Young AG: Do virus-resistant plants pose a threat to non-

261 target ecosystems? II. Risk assessment of an Australian pathosystem using multi-

$262 \quad$ scale field experiments. Austral Ecology 2009, 34:525-544.

263 * A two-year, multiple field site study that examines virus effects on perennial plant

264 fitness. This is one of only two publications that uses matrix-based demographic models

265 as a way to integrate information on virus effects across the entire life cycle.

266 20. Poorter H, Bühler J, van Dusschoten D, Climent J, Postma JA: Pot size matters: a meta-

267 analysis of the effects of rooting volume on plant growth. Functional Plant Biology

268 2012, 39:839-850.

269 21. Kulheim C, Agren J, Jansson S: Rapid regulation of light harvesting and plant fitness in

270 the field. Science 2002, 297:91-93.

271 22. Maskell LC, Raybould AF, Cooper JI, Edwards ML, Gray AJ: Effects of turnip mosaic

272 virus and turnip yellow mosaic virus on the survival, growth and reproduction of

273 wild cabbage (Brassica oleracea). Annals of Applied Biology 1999, 135:401-407.

274 *23. Malmstrom CM, Hughes CC, Newton LA, Stoner CJ: Virus infection in remnant native

275 bunchgrasses from invaded California grasslands. New Phytologist 2005, 168:217-

276230. 
*Afield study demonstrating that virus infection increased by invasive annual plants could negatively impact the performance of native perennial plants and contribute to the natives' decline.Unusual in its focus on multiple plant species and its three-year time span.

24. Funayama S, Terashima I, Yahara T: Effects of virus infection and light environment on population dynamics of Eupatorium makinoi (Asteraceae). American Journal of Botany 2001, 88:616-622.

25. Yahara T, Oyama K: Effects of virus infection on demographic traits of an agamospermous population of Eupatorium chinense (Asteraceae). Oecologia 1993, 96:310-315.

26. Goth RW, Wilcoxson RD: Effect of bean yellow mosaic on survival and flower formation in red clover. Crop Science 1962, 2:426-429.

27. Kelley SE: Viral pathogens and the advantage of sex in the perennial grass Anthoxanthum odoratum. Philosophical Transactions of the Royal Society of London 1994, 346:295-302.

*28. Power AG, Mitchell CE: Pathogen spillover in disease epidemics. The American Naturalist 2004, 164:S79.

*An important review that discusses how transmission of generalist pathogens may alter host community dynamics. This paper includes two novel field experiments that examine virus effects on host communities.

29. Sasu MA, Ferrari MJ, Du DL, Winsor JA, Stephenson AG: Indirect costs of a nontarget pathogen mitigate the direct benefits of a virus-resistant transgene in wild 
Cucurbita. Proceedings of the National Academy of Sciences of the United States of America 2009, 106:19067-19071.

30. Mackenzie S: Reciprocal Transplantation to Study Local Specialisation and the Measurement of Components of Fitness. PhD Dissertation, University College of North Wales, Bangor, Gwynedd, United Kingdom; 1985, 239 pp.

31. Catherall PL: Effects of barley yellow dwarf virus on the growth and yield of single plants and simulated swards of perennial rye-grass. Annals of Applied Biology 1966, 57:155-162.

32. Funayama-Noguchi S: Ecophysiology of Virus-Infected Plants: A Case Study of Eupatorium makinoi Infected by Geminivirus. Plant Biology 2001, 3:251-262.

*33. Remold SK: Unapparent virus infection and host fitness in three weedy grass species. Journal of Ecology 2002, 90:967-977.

*An early study that includes observational data on virus effects on plants and a particularly thoughtful discussion of how the high variability in plant traits in natural vegetation may affect our ability to detect virus effects on plant fitness.

34. Catherall PL, Griffiths E: Effects of streak virus on the growth of cocksfoot. Plant Pathology 1961, 10:72-77.

35. Ostazeski SA HP, Garrison CS Effect of Tobacco ringspot virus on yield persistence, flowering, and seed set of Lotus corniculatus.Phytopathology 1970, 60:1753-1755.

36. Gibbs A: A plant virus that partially protects its wild legume host against herbivores. Intervirology 1980, 13:42-47. 
37. Seabloom EW, Borer ET, Jolles A, Mitchell CE: Direct and Indirect Effects of Viral Grasslands. Journal of Ecology 2009, 97:1264-1273.

323 


\section{CAPTIONS}

Table 1. Field studies of effects of crop viruses on wild plant species. For Study Methods, see Box 1. Host types: EA - exotic annual; EP - exotic perennial; NA - native annual; NP - native perennial. *Biennial.

\section{Box 1. Methodological approaches for studying virus effects on wild plant fitness in the}

\section{field.}

\section{Figure 1.(A) Fitness components. The lifetime fitness of an individual plant depends on}

fitness components including its probabilities of survival to different life stages (s0, s1, s2), and, if it survives,on the probability that it flowers $(f p)$, the number of flowers it produces $(n f)$, and the number of seeds it produces per flower ( $f$ s)at each age (two-year life cycle shown). Virus infection, whether naturally occurring or experimentally induced, can occur at different points in the life cycle. For example, experimental inoculations can be performed on seedlings [23]or on mature plants [18]. The effect of the virus on plant fitness may depend on the timing of infection relative to plant life history events.(Note: We used a perennial sunflower as the focus of this figure; for this species, each inflorescence (“head”) consists of many flowers).(B)Fitness as a central mediator of effects in plant ecology and evolution. Virus infection can affect plant fitness (either negatively or positively), which in turn can alter plant population dynamics (changes in plant numbers over time), plant evolution, or plant community dynamics (changes in plant species composition over time). These three processes can in turn alter patterns of virus 
347 infection. For example, virus infection could decrease plant fitness, and if there is genetic

348 variation in susceptibility, plants may evolve to become more resistant. Greater resistance in the

349 plant population may reduce rates of virus infection (and possibly lead to evolutionary changes

350 in the virus). Note that to keep the figure simple, we have not included arrows between the ovals

351 for plant population dynamics, evolution, and community dynamics, even though these processes

352 certainly interact.

353

354 Figure 2.Observed effects of crop virus infection on wild plant species. For Study Methods,

355 see Box 1. Host types: EA - exotic annual; EP - exotic perennial; NA - native annual; NP -

356 native perennial. *Biennial. Effect codes: -, negative; 0, neutral; +, positive. For some measures,

357 more than one code is given, reflecting multiple treatments, plant taxa, viruses, or measurement

358 time points. Virus species studied include CMV (Cucumber mosaic virus, genus Cucumovirus,

359 family Bromoviridae), TLCV (Tomato leafcurl virus, genus Begomovirus, family

360 Geminiviridae),B/CYDV (Barley and Cereal yellow dwarf viruses, generaLuteovirusand

361 Polerovirus, family Luteoviridae), BYMV (Bean yellow mosaic virus, genus Potyvirus, family

362 Potyviridae), ClYVV (Clover yellow vein virus, genus Potyvirus, family Potyviridae ), CSV

363 (Cocksfoot streak virus, genus Potyvirus, family Potyviridae), TuMV (Turnip mosaic virus,

364 genus Potyvirus, family Potyviridae), ZYMV (Zucchini yellow mosaic virus,genus Potyvirus,

365 family Potyviridae), ArMV (Arabis mosaic virus, genus Nepovirus, family Secoviridae), TRSV

366 (Tobacco ringspot virus, genus Nepovirus, family Secoviridae), and TYMV (Turnip yellow

367 mosaic virus, genus Tymovirus, family Tymoviridae). 


\section{Box 1. Methodological approaches for studying virus effects on wild plant fitness in the field.}

\section{Method 1. Natural plant populations with naturally acquired infection}

Fitness components of naturally established plants exposed to natural infection are measured and related to their infection status [33]

\section{Advantages}

- Describes ecologically relevant virus interactions in natural vegetation

- No need to directly manipulate viruses; few permitting requirements.

- Avoids cost of managing experimental plantings; feasible to survey large area. Disadvantages

- Difficult to interpret causality (e.g., EW Seabloom, et al. [37]). Non-random virus acquisition is a particular challenge. For example, if vectors prefer larger [or smaller] plants, infection status may be associated with size because of transmission dynamics and not necessarily because infection alters plant growth.

- Confounding variability may be introduced if plants gain infection at different life stages or become co-infected with multiple viruses.

- Mortality of young plants may be hard to detect.

\section{Method 2. Experimental plant populations with naturally acquired infection}

Experimental plant populations with known properties are established in the field and allowed to acquire natural infection from the environment. Plants might be clones (e.g., modifying the method of S Mackenzie [30]) or virus-susceptible and virus-resistant lines that are otherwise similar, such as in transgenic populations [29].

\section{$\underline{\text { Advantages }}$}

- Greater control of plant material facilitates interpretation of results

- Preserves natural infection process; usually permits not required unless GMO.

- Effective for testing questions about factors controlling infection rates and patterns of virus accumulation over time

\section{Disadvantages}

- Natural infection rates may be too low or too high to achieve experimental goals,

- Confounding variability may be introduced through process of natural inoculation.

\section{Method 3. Experimental plant populations with experimental infection}

Individual experimental plants or plant communities are directly inoculated or mock-inoculated with a known virus. For vector-borne viruses, individual plants are typically infected indoors to contain vector movement, and then are treated with pesticide and transplanted outdoors. For mechanically transmitted viruses, field inoculation may be more feasible [18]. Depending on biosafety requirements, efforts may [23] or may not [22] be required to limit subsequent vector contact with plants. Alternatively, for community-level experiments, viruliferous and non- 
viruliferous vectors may be released within caged field plots for a determined time period and then killed [28].

$\underline{\text { Advantages }}$

- Strongest means of quantifying direct, causal relationships between virus infection and host plant fitness.

$\underline{\text { Disadvantages }}$

- Biosafety concerns limit studies to specific low-threat viruses or environments.

- Logistically demanding; often favor experimental designs in which plants are inoculated when young and most easily handled.

Method 4. Natural plant populations with experimental infection.

This fourth method has not been used, to our knowledge. Given that it would address causal relationships between infection and plant fitness in the context of naturally growing vegetation, this approach would most directly explore whether infection alters plant fitness field populations, Variability within natural populations may, however, make results difficult to interpret. 
Table 1. Field studies of effects of crop viruses on fitness or fitness components of wild plant species. For Study Method, see Box 1. Host types: EA - exotic annual; EP - exotic perennial; $\mathrm{NA}$ - native annual; NP - native perennial. *Biennial.

\begin{tabular}{|c|c|c|c|c|}
\hline $\begin{array}{l}\text { Virus Family \& } \\
\text { Species }\end{array}$ & $\begin{array}{l}\text { Host } \\
\text { Type }\end{array}$ & Host Genus or Genera and Study Conditions \& reference & $\begin{array}{l}\text { Study } \\
\text { Method }\end{array}$ & Ref. \\
\hline $\begin{array}{l}\text { Bromoviridae } \\
\mathrm{CMV}^{1}\end{array}$ & NA & Cucurbita; 1-yr study in Mississippi (USA) field & 3 & [16] \\
\hline $\begin{array}{l}\text { Geminiviridae } \\
\text { TLCV }^{2}\end{array}$ & NP & Eupatorium; shaded and gap sites in Japanese forest. & 1 & $\begin{array}{l}{[21,} \\
22]\end{array}$ \\
\hline \multirow{10}{*}{$\begin{array}{l}\text { Luteovirdae } \\
\text { B/CYDV }\end{array}$} & EA & Bromus, Setaria; survey of experimental oat plot, New York (USA) & 1 & [31 ] \\
\hline & & & & \\
\hline & EA & Avena, Bromus; survey of 18 grasslands along North American west coast & 1 & [35] \\
\hline & NP & Festuca; 1 -yr study of restoration planting in California (USA) field & 2 & [20] \\
\hline & NP & $\begin{array}{l}\text { Lolium; 2-yr field study of individuals and simulated swards with clover and } \\
\text { clipping, Wales (UK) }\end{array}$ & 3 & [29] \\
\hline & EP & Anthoxanthum; 1-yr study in mown field, North Carolina (USA) & 3 & [25] \\
\hline & EA & $\begin{array}{l}\text { Avena, Digitaria, Lolium, Setaria; 1-yr study in New York (USA) of caged } \\
\text { experimental communities }\end{array}$ & 3 & [26] \\
\hline & NP & $\begin{array}{l}\text { Elymus, Festuca, Hordeum, Koeleria, Nassella (Stipa); 3-yr study in California } \\
\text { (USA) field of individuals from multiple populations. }\end{array}$ & 3 & [20] \\
\hline & EA & Bromus; 1-yr study California (USA) & 3 & {$[20]$} \\
\hline & NP & $\begin{array}{l}\text { Elymus, Nassella (Stipa); 1-yr study in California (USA) ag. field, with } \\
\text { competition \& clipping }\end{array}$ & 3 & [13] \\
\hline $\begin{array}{l}\text { Potyviridae } \\
\text { BYMV }^{4}\end{array}$ & \multicolumn{3}{|c|}{ BYMV $^{4}$} & {$[24]$} \\
\hline ClYVV $^{5}$ & EP & $\begin{array}{l}\text { Trifolium; } 18 \text {-month study at grassland \& woodland sites in south-east } \\
\text { Australia, with competition in grassland site }\end{array}$ & 3 & {$[17]$} \\
\hline $\mathrm{CSV}^{6}$ & NP & Dactylis; ca. 18-month study of artificial swards, with clipping, Wales (UK) & 3 & {$[32]$} \\
\hline TuMV $^{7}$ & NP* & Brassica; 2-yr-study in Dorset (UK) fallow field & 3 & {$[23]$} \\
\hline \multirow[t]{2}{*}{$\mathrm{ZYMV}^{8}$} & NA & $\begin{array}{l}\text { Cucurbita; Pennsylvania (USA) ag. field, with cucumber beetles \& bacterial } \\
\text { infection }\end{array}$ & 2 & {$[27]$} \\
\hline & NA & Cucurbita; 1-yr study in Mississippi (USA) field & 3 & {$[16]$} \\
\hline $\begin{array}{l}\text { Secoviridae } \\
\text { ArMV }^{9}\end{array}$ & NP & Primula; five sites with natural populations in Wales (UK) & 2 & [28] \\
\hline TRSV $^{10}$ & EP & Lotus; 1 - to 2-yr field study in Maryland (USA) & 3 & [33] \\
\hline $\begin{array}{l}\text { Tymoviridae } \\
\text { TYMV }^{11}\end{array}$ & NP* & Brassica; 2-yr-study in Dorset (UK) fallow field & 3 & [23] \\
\hline
\end{tabular}

${ }^{1}$ Cucumber mosaic virus, ${ }^{2}$ Tomato leaf curl virus, ${ }^{3}$ Barley and Cereal yellow dwarf viruses, ${ }^{4}$ Bean yellow mosaic virus, ${ }^{5}$ Clover yellow vein virus, ${ }^{6}$ Cocksfoot streak virus, ${ }^{7}$ Turnip mosaic virus, ${ }^{8}$ Zucchini yellow mosaic virus, ${ }^{9}$ Arabis mosaic virus, ${ }^{10}$ Tobacco ringspot virus, and ${ }^{11}$ Turnip yellow mosaic virus 
(a)
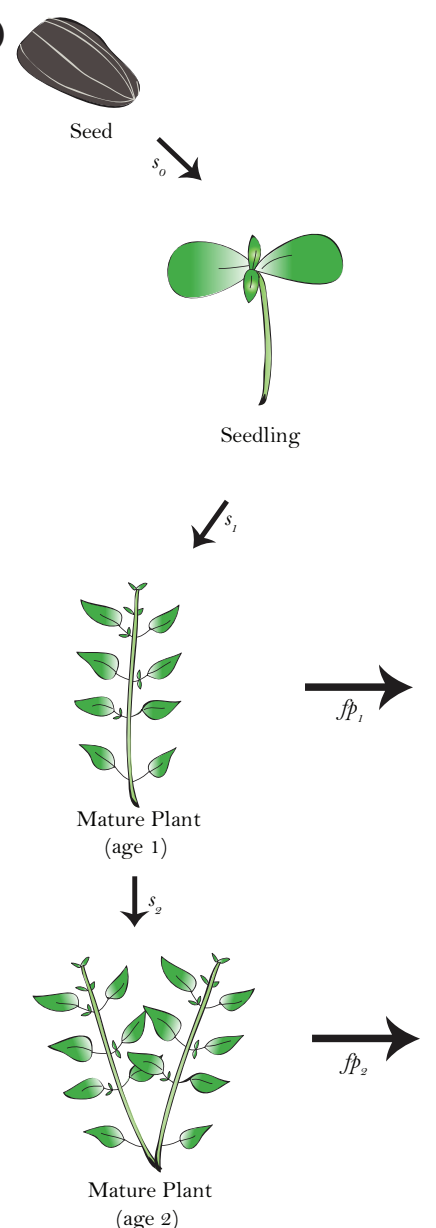

(age 2)

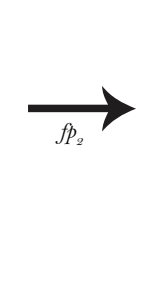

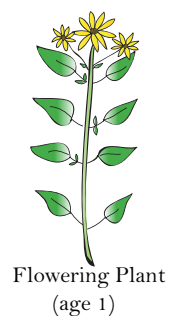

(b)
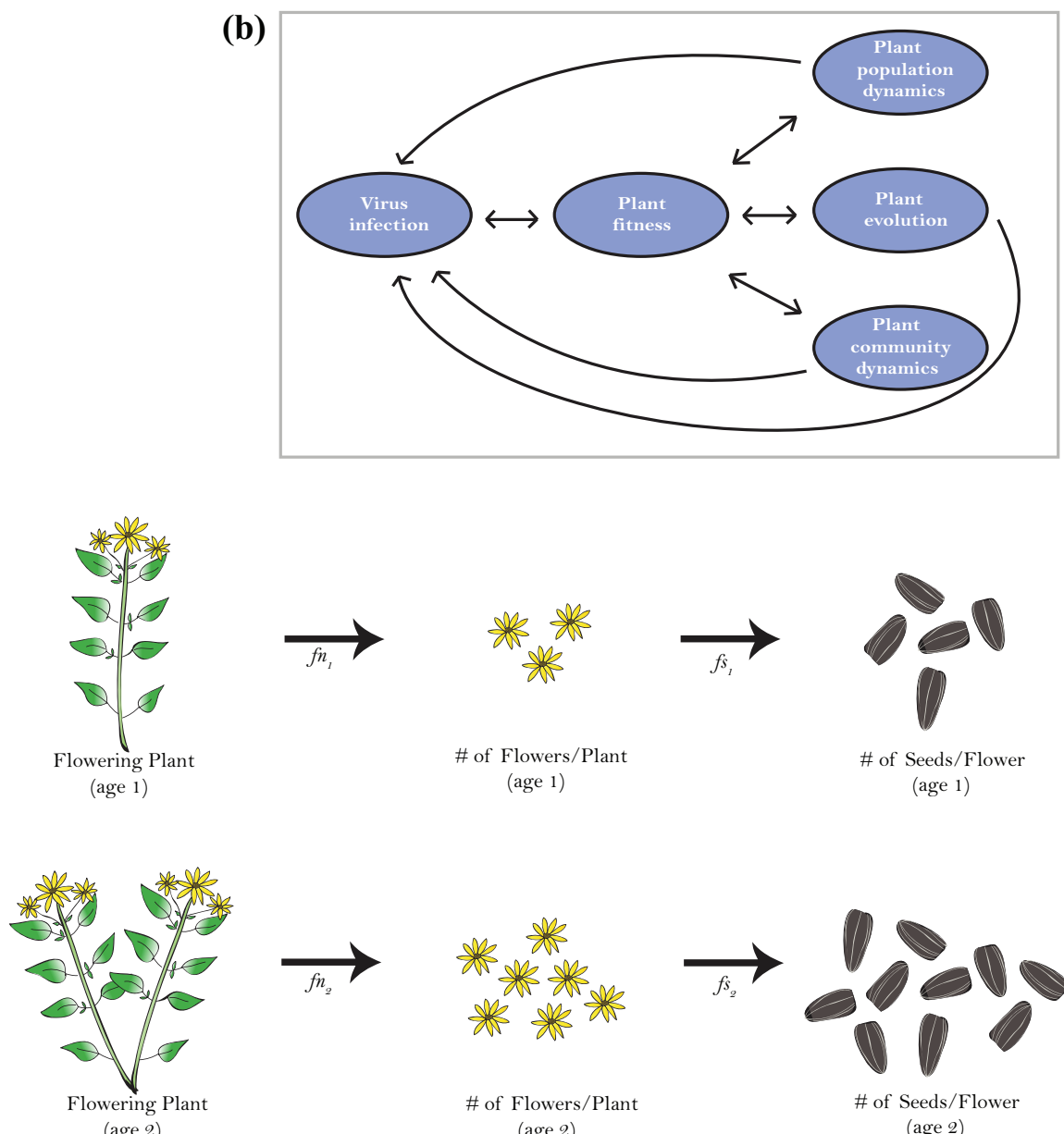

(age 2)

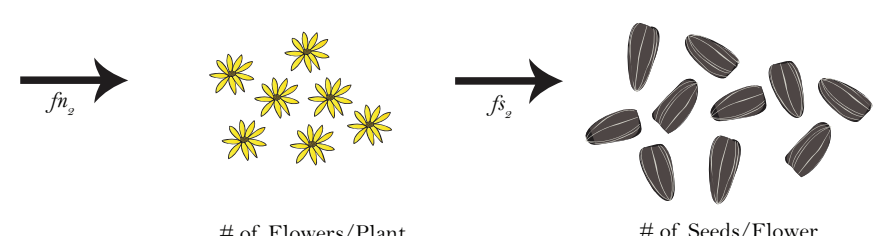

\# of Flowers/Plant (age 2)
\# of Seeds/Flower (age 2) 
Figure 2

\begin{tabular}{|c|c|c|c|c|c|c|c|c|c|c|c|c|c|c|c|c|c|c|c|c|c|c|c|c|}
\hline \multicolumn{6}{|l|}{ Virus study } & \multicolumn{12}{|c|}{ Fitness components } & \multicolumn{7}{|c|}{ Growth metrics } \\
\hline Virus family & Virus & Method & $\begin{array}{l}\text { Host } \\
\text { Type }\end{array}$ & Host Genus & Ref \# & 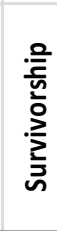 & 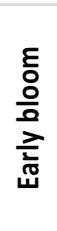 & 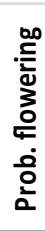 & 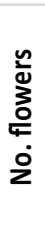 & 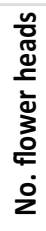 & 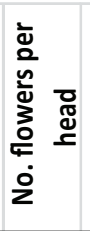 & 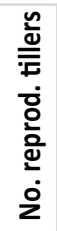 & 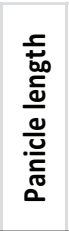 & 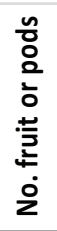 & 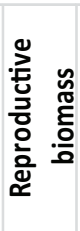 & 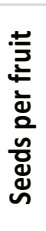 & 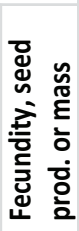 & 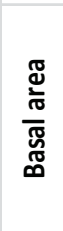 & 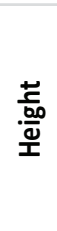 & 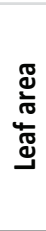 & 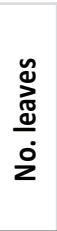 & 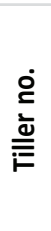 & 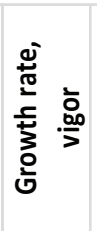 & 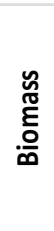 \\
\hline Bromoviridae & $\mathrm{CMV}$ & 3 & NA & Cucurbita & 18 & & & & & & & & & 0 & & 0 & & & & & & & & \\
\hline Geminiviridae & TLCV & 1 & NP & Eupatorium & 24,25 & - & & 0 & & & & & & & & & - & & - & & & & - & \\
\hline \multirow[t]{9}{*}{ Luteoviridae } & B/CYDV & 1 & EA & Poaceae spp. & 33 & & & & & & & -+ & $-0+$ & & & & & & -0 & & & + & & -0 \\
\hline & B/CYDV & 1 & EA & Poaceae spp. & 37 & & & & & & & & & & & & 0 & & & & & & & \\
\hline & B/CYDV & 2 & NP & Festuca & 23 & & & & - & & & & & & & & - & 0 & & & & & & 0 \\
\hline & B/CYDV & 3 & NP & Lolium & 31 & $\mathbf{0}$ & + & & & & & & & & & & & & - & & & $0+$ & & -+ \\
\hline & B/CYDV & 3 & EP & Anthoxanthum & 27 & & & & - & & & & & & & & & & & & & - & & \\
\hline & B/CYDV & 3 & EA & Poaceae spp. & 28 & & & & & & & & & & -0 & & & & & & & & & -0 \\
\hline & B/CYDV & 3 & NP & Poaceae spp. & 23 & -0 & & & & & & -0 & & & & & -0 & -0 & & & & & & -0 \\
\hline & B/CYDV & 3 & EA & Bromus & 23 & & & & & & & & & & & & - & & & & & & & - \\
\hline & B/CYDV & 3 & NP & Poaceae spp. & 15 & - & & & & & & & & & & & - & - & - & & & - & & - \\
\hline \multirow[t]{6}{*}{ Potyviridae } & BYMV & 2 & EP & Trifolium & 26 & & & & & - & - & & & & & & & & & & & & & \\
\hline & CIYVV & 3 & EP & Trifolium & 19 & - & & & & & & & & & & & - & & & & & & - & \\
\hline & CSV & 3 & NP & Dactylis & 34 & - & & & & & & & & & & & & & & & & & & - \\
\hline & TuMv & 3 & $N P^{*}$ & Brassica & 22 & - & & 0 & & & & & & - & & & - & & 0 & 0 & 0 & & & \\
\hline & ZYMV & 2 & NA & Cucurbita & 29 & & & & - & & & & & - & & & & & & & & & & \\
\hline & ZYMV & 3 & NA & Cucurbita & 18 & & & & & & & & & 0 & & 0 & & & & & & & & \\
\hline \multirow[t]{2}{*}{ Secoviridae } & ArMV & 2 & NP & Primula & 30 & & + & & 0 & & & & & & & & & & & & - & & & \\
\hline & TRSV & 3 & EP & Lotus & 35 & -0 & & & & - & -0 & & & & & - & - & & & & & & - & \\
\hline Tymoviridae & TYMV & 3 & NP* & Brassica & 22 & - & & - & & & & & & - & & & - & & - & - & - & & & \\
\hline
\end{tabular}


Field methods of studying virus effects on plant fitness
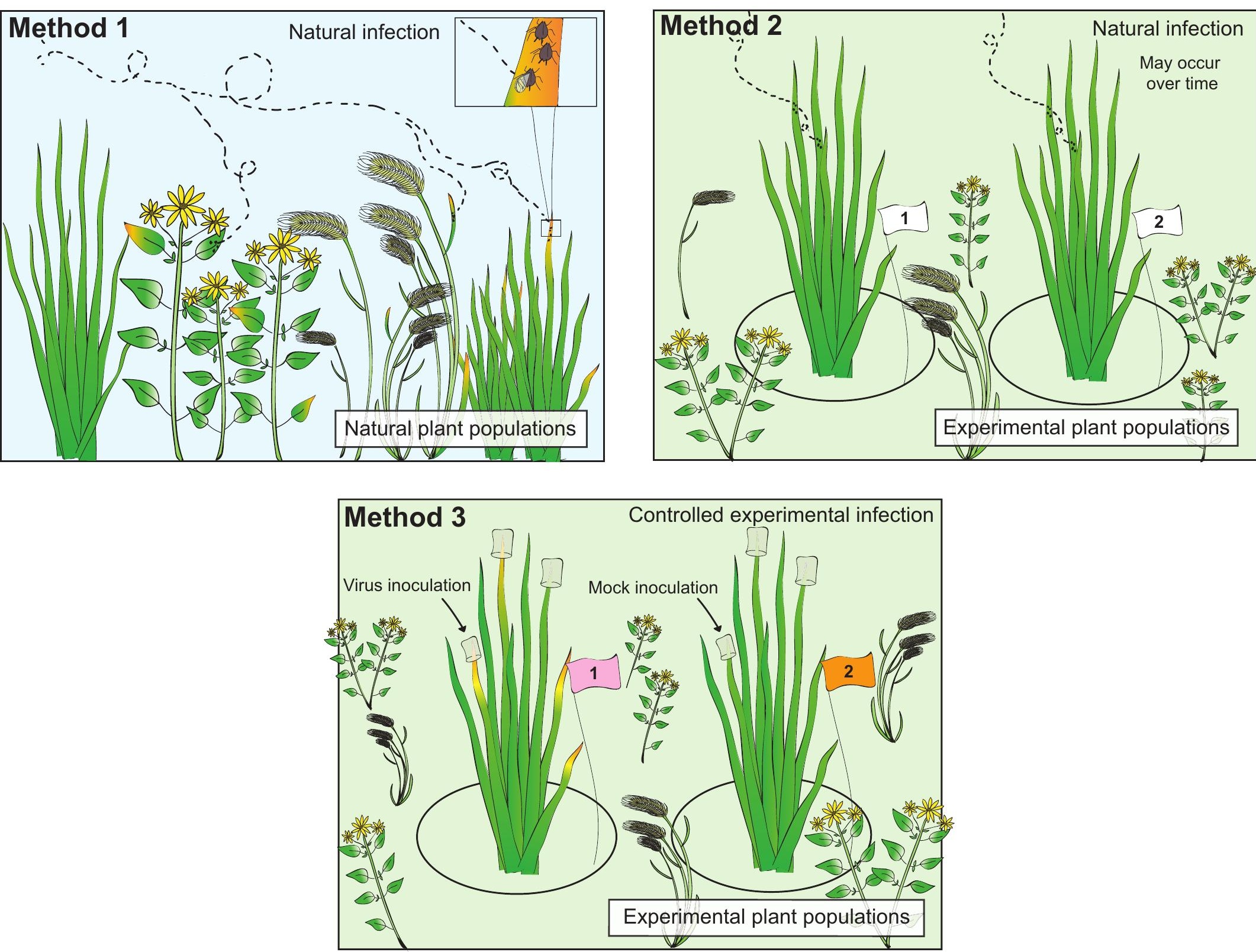